\title{
Vitamin B6-Dependent Enzymes in the Human Malaria Parasite Plasmodium falciparum: A Druggable Target?
}

\author{
Thales Kronenberger, ${ }^{1}$ Jasmin Lindner, ${ }^{1}$ Kamila A. Meissner, ${ }^{1}$ Flávia M. Zimbres, ${ }^{1}$ \\ Monika A. Coronado, ${ }^{2}$ Frank M. Sauer, ${ }^{1}$ Isolmar Schettert, ${ }^{3}$ and Carsten Wrenger ${ }^{1}$ \\ ${ }^{1}$ Unit for Drug Discovery, Department of Parasitology, Institute of Biomedical Science, University of São Paulo, \\ Avenida Professor Lineu Prestes 1374, 05508-000 São Paulo, SP, Brazil \\ ${ }^{2}$ Multi User Center for Biomolecular Innovation, Department of Physics, São Paulo State University, UNESP/IBILCE, \\ C. Postal 136, 15054-000 São José do Rio Preto, SP, Brazil \\ ${ }^{3}$ Laboratory of Genetics and Molecular Cardiology, Heart Institute (InCor), Avenida Doctor Eneas de Carvalho Aguiar 44, \\ 05403-000 São Paulo, SP, Brazil \\ Correspondence should be addressed to Carsten Wrenger; cwrenger@icb.usp.br
}

Received 17 May 2013; Revised 24 October 2013; Accepted 28 November 2013; Published 9 January 2014

Academic Editor: Ashley M. Buckle

Copyright (C) 2014 Thales Kronenberger et al. This is an open access article distributed under the Creative Commons Attribution License, which permits unrestricted use, distribution, and reproduction in any medium, provided the original work is properly cited.

\begin{abstract}
Malaria is a deadly infectious disease which affects millions of people each year in tropical regions. There is no effective vaccine available and the treatment is based on drugs which are currently facing an emergence of drug resistance and in this sense the search for new drug targets is indispensable. It is well established that vitamin biosynthetic pathways, such as the vitamin B6 de novo synthesis present in Plasmodium, are excellent drug targets. The active form of vitamin B6, pyridoxal 5-phosphate, is, besides its antioxidative properties, a cofactor for a variety of essential enzymes present in the malaria parasite which includes the ornithine decarboxylase (ODC, synthesis of polyamines), the aspartate aminotransferase (AspAT, involved in the protein biosynthesis), and the serine hydroxymethyltransferase (SHMT, a key enzyme within the folate metabolism).
\end{abstract}

\section{Introduction}

Malaria is a devastating infectious disease, which causes serious problems in tropical and subtropical areas. According to the World Health Organization (WHO), the population of more than 100 countries is exposed to malaria parasites [1]. The causative agent of malaria is belonging to the genus Plasmodium, which can affect almost all vertebrates; however, only five species have been reported to be infective for humans, $P$. falciparum, $P$. vivax, $P$. ovale, $P$. malariae, and P. knowlesi [2]. The transmission of the parasite occurs via a blood meal of the Anopheles vector. Thereby, sporozoites are transmitted to the vertebrate host and the comprehensive life cycle of the pathogen is initiated [3]. In the past, several attempts to control the disease have been undertaken to exterminate the vector with insecticide. However, due to spreading drug resistance, these insecticides lost their efficacy [4]. A similar situation is present for the treatment of patients, since an effective vaccine is not yet available and the medication of malaria is solely based on drugs $[5,6]$.

The folate (vitamin B9) metabolism is a validated drug target in several infectious diseases and its biosynthesis is not present in humans. Folate is an essential cofactor in enzymatic reactions transferring one-carbon $(\mathrm{Cl})$ groups $[7,8]$ and prominent antimalarials such as pyrimethamine and cycloguanil (inhibitors of the dihydrofolate reductase) and the sulfa drugs against the dihydropteroate synthase are well characterised within the vitamin B9 metabolism [7, 8]. However-among others-resistance is also rising against this metabolic pathway. Currently, there is a move towards artemisinin-based combination therapies (ACTs) $[9,10]$.

As already indicated above, due to the fact that currently no effective vaccine is available and the parasite's speed in developing resistance against almost all chemotherapeutic compounds is alarming, there is an urgent need to discover 


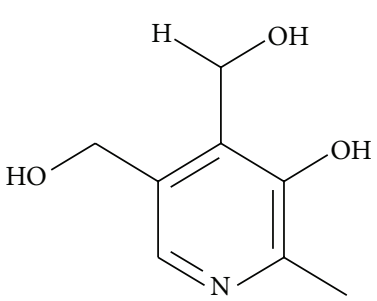

(a)

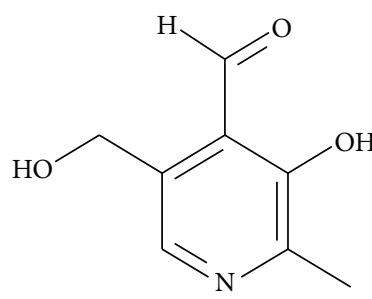

(b)

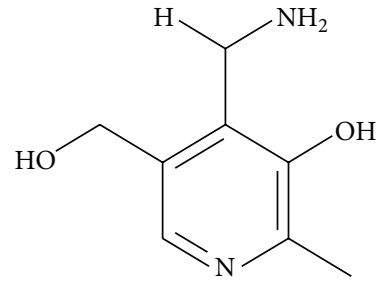

(c)

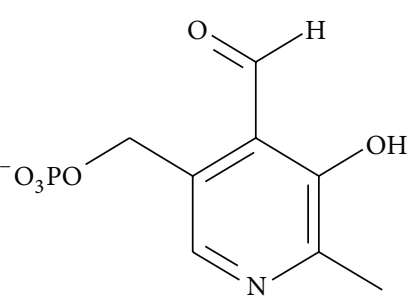

(d)

FIGURE 1: Chemical structures of vitamin B6: (a) pyridoxine, (b) pyridoxal, (c) pyridoxamine, and (d) its active form pyridoxal 5-phosphate.

novel drug-targets, which are subsequently exploitable for the design of new therapeutics against the malaria pathogen $[11,12]$. In the search for novel antimalarials, attention has been drawn on selective interference with the parasite's metabolism without harming the human host [13]. In this sense promising drug targets are vitamin biosynthetic pathways.

Vitamins are molecules which have a variety of functions in nature. They act as antioxidants, as precursors in electron carrying processes, or are involved in enzymatic reactions by acting as cofactors in metabolic pathways such as the vitamins of the B-family [14]. Mammals generally depend on the uptake of vitamins, unlike other groups, such as bacteria, plants, and fungi which can synthesize them de novo. Some apicomplexan parasites possess also vitamin biosynthetic pathways which represent attractive drug targets to interfere with $[7,13]$.

So far, three vitamin biosynthetic pathways have been identified in malaria parasites $[7,13]$. Besides the occurrence of the biosynthesis for folate (vitamin B9) and the thiamine (vitamin B1) biosynthesis, Plasmodium possesses also a vitamin B6 biosynthetic pathway. Vitamin B6 is designated for six vitamers: pyridoxine $(\mathrm{PN})$, pyridoxamine $(\mathrm{PM})$, pyridoxal $(\mathrm{PL})$, and their respective phosphorylated forms. The differente molecules differentiate in their substitutions at the 4th position of the pyridine ring (Figure 1). However, pyridoxal 5-phosphate (PLP) is the only active form of the enzymatic cofactor which is mainly involved in decarboxylation and transamination reactions [15].

Up to now, two different vitamin B6 biosynthesis pathways are described: (i) the 1-deoxy-D-xylulose 5-phosphate (DOXP)-dependent pathway is found in some proteobacteria and is leading to pyridoxine 5-phosphate [16-18]; (ii) the second pathway, the DOXP-independent pathway, is found in plants, fungi, and the apicomplexan parasites Plasmodium and Toxoplasma gondii [19-21].

Historically, the DOXP-independent pathway was identified in plants and ascribed to oxidative stress response [22, 23]. Afterwards, the analysis of this pathway discovered the biosynthesis of PLP, which is mediated by an enzyme complex (PLP-synthase) composed of a core of $12 \mathrm{Pdxl}$ (also known as SNZ1 in yeast) individually surrounded by $12 \mathrm{Pdx} 2$ (called SNO1 in yeast) $[24,25]$. The reaction mechanism has already been studied in some detail, starting with the deamination of glutamine to glutamate which is catalysed by Pdx2, subsequently, the ammonia group is channelled to Pdxl, where it is combined with the two other substrates, ribose 5-phosphate and glyceraldehyde 3-phosphate, leading to the active cofactor $[24,26]$. This complex has already been tested for its druggability by performing in silico screens in order to dock compounds into the active site. Identified compounds were further employed in in vitro assays using recombinantly expressed enzymes. The best compound derived from this screen was 4-phospho-D-erythronhydrazide, which revealed an $\mathrm{IC}_{50}$-value of $10 \mu \mathrm{M}$ in cell culture experiments [27].

Moreover, besides the well-established function of vitamin B6 in acting as a cofactor, the molecule is also involved in the combat against reactive oxygen species (ROS), in particular against singlet oxygen $[22,28]$. This additional mode of action is especially of relevance for the intraerythrocytic stage of the human malaria parasite, because Plasmodium is permanently exposed to ROS during proliferation within the erythrocytes due to the oxidative environment of its host cell which is accompanied by the parasite-driven haemoglobin degradation $[29,30]$.

Additionally, the parasite's genome encodes also for an interconversion pathway which consists of the pyridoxal kinase $(\mathrm{PdxK})$ and a phosphatase $[4,7]$. The latter reveals a broad substrate spectrum and therefore it is questionable whether this enzyme is solely responsible for the dephosphorylation of $\mathrm{B} 6$ vitamers $[20,31]$. The PdxK catalyses the phosphorylation of pyridoxal but also accepts the other B6 vitamers as substrate $[20,32]$. The presence of bothbiosynthetic and interconversion - pathways remains still for elucidation since the parasite is able to generate PLP via two pathways which would obviously emphasise an uptake of B6 vitamers [4].

In P. falciparum, the PdxK enzyme was already exploited as drug target by channelling prodrugs into the parasite's metabolism. Pyridoxyl-tryptophan chimeras were converted into their respective phosphorylated forms by the PdxK. Subsequently, these molecules were shown to interfere with PLP-dependent enzymes by inhibiting their catalyses and hence the growth of the parasite [32].

\section{PLP-Dependent Enzymes}

PLP-dependent enzymes are characterised by their broad range of enzymatic activities and their participations in different metabolic pathways $[15,52]$. They are mainly concentrated within the amino-acid metabolism [53]. Besides the glycogen phosphorylases, which follow a different mechanism [54, 55], PLP-dependent enzymes bind PLP during catalysis covalently to the respective substrate by acting as an electrophilic 
TABLE 1: Different classes of PLP-dependent enzymes according to [15, 33].

\begin{tabular}{lll}
\hline Group number & Enzyme class/activity & Representative enzymes \\
\hline 1 & Aminotransferases and the amino-acid decarboxylases & $\begin{array}{l}\text { Serine hydroxymethyltransferase (SHMT) and the } \\
\text { aspartate aminotransferase (AspAT, prototype) } \\
\text { Serine and threonine dehydratases and the tryptophan } \\
\text { synthase (prototype) }\end{array}$ \\
3 & Replacement and elimination of $\mathrm{C}_{\beta}$-groups & Alanine racemase \\
4 & $\begin{array}{l}\text { Interconversion of L- and D-amino acids with a } \\
\text { common folding (alpha/beta) })_{8}\end{array}$ & D-Alanine aminotransferase \\
5 & Alanine aminotransferase & Glycogen phosphorylase \\
6 & Glycogen phosphorylase & D-Lysine 5,6-aminomutase \\
7 & 5,6-Aminomutase & Lysine 2,3-aminomutase \\
\hline
\end{tabular}

stabilizer of the carbanion intermediate [56]. In the past, a few attempts have been undertaken to classify PLP-dependent enzymes according to their activities and evolutionary history by splitting them into four major classes $[57,58]$. Due to their conservation in the nature, it has been suggested that PLPdependent enzymes derived from a common ancestor before division into the three kingdoms of life occurred [57].

Afterwards, this classification was refined by analysing genomic and structural information $[15,33]$ which led to the sorting of PLP-dependent enzymes into seven groups (Table 1).

Kappes and collaborators suggested that, because of the existing metabolic diversity, PLP-dependent enzymes in protozoan parasites would have potential to be good drug targets [59]. Most of the enzymes found (at least 2/3) belong to group I, followed by the less expressive group II, while the groups IV and V are rare and the groups VI and VII are almost inexistent. Recent genome database analyses of different parasites identified a minimal set of enzymes that are highly abundant which includes the serine hydroxymethyltransferase (SHMT), the aspartate aminotransferase (AspAT), the alanine transaminase, the branched-chain amino-acid transaminase, and the cysteine desulfurase [59].

Moreover, the comparison of all available genomes of free-living organisms revealed that only two EC-classified enzymes are always present: the AspAT (EC 2.6.1.1) and the SHMT (EC 2.1.2.1), which underlines the fundamental importance of these enzymes [15].

Additionally, several other PLP-dependent enzymes have already been exploited as drug targets such as the $\gamma$ aminobutyric acid GABA aminotransferase by the drug vigabatrin for treatment of epilepsy [60], the alanine racemase in microbicides [61], or the ornithine decarboxylase (ODC) in cancer research [62]. In particular, the ODC was also subject to drug discovery approaches against protozoan parasites but not limited as outlined below to the aspartate aminotransferase (AspAT) and the serine hydroxymethyltransferase (SHMT). However, the occurrence of PLP-dependent enzymes in the malaria parasite is not restricted to these three proteins as shown in Table 2.

\section{Ornithine Decarboxylase (ODC)}

As already outlined above, vitamin B6-dependent enzymes play central roles not only in the metabolism of amino acids but also in the polyamine synthesis. Polyamines are simply structured aliphatic nitrogenous bases containing an essential role in cell growth, proliferation, and differentiation due to their stabilizing effect on macromolecules such as nucleic acids, proteins, and lipids. Their function is considered to be based on reversible ionic interactions with the negatively charged macromolecules [63-65].

The ornithine decarboxylase (ODC) is a PLP-dependent enzyme (Figure 2) which acts as a key regulator in the polyamine biosynthesis by decarboxylating ornithine to the polyamine putrescine-the first step in this synthesis. In contrast to ornithine, the other precursor of the polyamine synthesis, $S$-adenosylmethionine (AdoMet), is synthesized from methionine and ATP by the enzyme AdoMet synthase. AdoMet is also used to generate the polyamines spermidine and spermine. $P$. falciparum possesses a unique polyamine biosynthesis due to the bifunctional organisation of its key enzymes, $S$-adenosylmethionine decarboxylase (AdoMetDC) and ornithine decarboxylase (ODC) [42, 66]. Thereby, both enzymes appear as the bifunctional AdoMetDC/ODC whose organisation was discussed as an advantage in substrate channelling [66].

There are more bifunctional proteins known in $P$. falciparum such as the dihydrofolate reductase-thymidylate synthase (DHFR-TS) which is also present in other protozoa $[67,68]$, the dihydro-6-hydroxymethylpterin pyrophosphokinase-dihydropteroate synthase (PPPK-DHPS) [69], the glucose-6-phosphate dehydrogenase/6-phosphogluconolactonase [70], and the guanylate cyclase/adenylate cyclase [71].

Among others, this unique organisation of the PfODC has been discussed to be an attractive drug target [72]. As the amino acid sequence of $P f O D C$ shares about $39 \%$ identity to the human homologue, complications in rational drug design of $P f O D C$-specific lead compounds could be a crucial issue [39]. Generally, there are three different strategies of inhibitor design. A formerly used strategy for designing inhibitors of vitamin B6-dependent enzymes is based on coenzymesubstrate conjugates that cannot be processed by the enzyme in their reduced form [73].

Another-already validated-strategy is the use of substrate analogues in order to inhibit enzyme catalysis like the specific ODC inhibitor difluoromethylornithine (DFMO), originally designed as an anticancer agent. DFMO blocks the erythrocytic schizogony of $P$. falciparum in cell culture at the 
Table 2: PLP-dependent enzymes in Plasmodium.

\begin{tabular}{|c|c|c|c|c|c|c|}
\hline $\begin{array}{l}\text { EC- } \\
\text { number }\end{array}$ & EC-name & $\begin{array}{l}\text { PlasmoDB } \\
\text { number }\end{array}$ & $\begin{array}{c}\text { Annotation according to } \\
\text { PlasmoDB }\end{array}$ & Pathway & Inhibitors & References \\
\hline 2.1.2.1 & $\begin{array}{c}\text { Glycine } \\
\text { hydroxymethyltransferase }\end{array}$ & PFL1720w & $\begin{array}{c}\text { Serine } \\
\text { hydroxymethyltransferase }\end{array}$ & Folate metabolism & $\begin{array}{l}\text { 1843U89, AG331, AG337, } \\
\text { D1694, GR1, pemetrexed, } \\
\text { pyrimethamine, } \\
\text { WR99210, methotrexate, } \\
\text { glycine (competitively) }\end{array}$ & {$[34,35]$} \\
\hline 2.3.1.37 & $\begin{array}{l}\text { 5-Aminolevulinate } \\
\text { synthase }\end{array}$ & PFL2210w & $\begin{array}{c}\text { ALA synthase } \\
\text { (aminolevulinate } \\
\text { synthase) }\end{array}$ & $\begin{array}{l}\text { Tetrapyrrole } \\
\text { biosynthesis }\end{array}$ & $\begin{array}{c}\text { Aminomalonate, } \\
\text { Ethanolamine, Hemin }\end{array}$ & {$[36]$} \\
\hline 2.6.1.1 & $\begin{array}{c}\text { Aspartate } \\
\text { aminotransferase }\end{array}$ & PFB0200c & $\begin{array}{c}\text { Aspartate } \\
\text { aminotransferase }\end{array}$ & $\begin{array}{l}\text { Amino acid and } \\
\text { pyrimidine } \\
\text { metabolism }\end{array}$ & $\begin{array}{l}\text { Inhibited by his own } \\
\text { N-terminal peptide }\end{array}$ & {$[37]$} \\
\hline 2.6.1.13 & $\begin{array}{c}\text { Ornithine } \\
\text { aminotransferase }\end{array}$ & PFF0435w & $\begin{array}{c}\text { Ornithine } \\
\text { aminotransferase }\end{array}$ & Argnine metabolism & L-canaline & {$[38]$} \\
\hline 2.6.1.57 & $\begin{array}{l}\text { Aromatic amino-acid } \\
\text { transaminase }\end{array}$ & PFB0200c & $\begin{array}{c}\text { Aspartate } \\
\text { aminotransferase }\end{array}$ & $\begin{array}{l}\text { Amino acid and } \\
\text { pyrimidine } \\
\text { metabolism }\end{array}$ & - & - \\
\hline 4.1.1.17 & Ornithine decarboxylase & PF10_0322 & $\begin{array}{l}\text { S-Adenosylmethionine } \\
\text { decarboxylase/ornithine } \\
\text { decarboxylase } \\
\text { (bifunctional) }\end{array}$ & $\begin{array}{l}\text { Polyamine } \\
\text { biosynthesis }\end{array}$ & $\begin{array}{c}\text { Alpha- } \\
\text { difluoromethylornithine, } \\
\text { alpha-difluoroornithine, } \\
\text { CGP52622A, } \\
\text { CGP54619A, putrescine } \\
\text { (feedback control) }\end{array}$ & [39-44] \\
\hline 4.1.3.38 & $\begin{array}{c}p \text {-Aminobenzoic acid } \\
\text { synthetase }\end{array}$ & PFI1100w & $\begin{array}{l}p \text {-Aminobenzoic acid } \\
\text { synthetase, putative }\end{array}$ & Folate biosynthesis & - & - \\
\hline 2.6.1.7 & $\begin{array}{l}\text { 3-Hydroxykynurenine } \\
\text { transaminase }\end{array}$ & & $\begin{array}{l}\text { Present in the insect } \\
\text { vector: Anopheles }\end{array}$ & $\begin{array}{l}\text { Xanthurenic acid is } \\
\text { needed by the } \\
\text { parasite for } \\
\text { proliferation/ } \\
\text { development }\end{array}$ & - & {$[45]$} \\
\hline \multicolumn{7}{|c|}{ Putative PLP-dependent enzymes } \\
\hline 2.3.1.50 & $\begin{array}{c}\text { Serine } \\
\text { C-Palmitoyltransferase }\end{array}$ & PF14_0155 & $\begin{array}{c}\text { Serine } \\
\text { C-Palmitoyltransferase }\end{array}$ & $\begin{array}{l}\text { Sphingolipid } \\
\text { metabolism }\end{array}$ & - & - \\
\hline 2.6.1.42 & $\begin{array}{l}\text { Branched-chain } \\
\text { amino-acid } \\
\text { aminotransferase }\end{array}$ & PF14_0557 & $\begin{array}{l}\text { "Conserved Plasmodium } \\
\text { protein" }\end{array}$ & $\begin{array}{l}\text { Pantothenate and } \\
\text { CoA biosynthesis }\end{array}$ & - & - \\
\hline 2.8.1.7 & Cysteine desulfurase & $\begin{array}{l}\text { PF07_0068, } \\
\text { MAL7P1.150 }\end{array}$ & $\begin{array}{c}\text { Cysteine desulfurase, } \\
\text { putative }\end{array}$ & $\begin{array}{l}\text { Iron-sulfur cluster } \\
\text { synthesis }\end{array}$ & - & - \\
\hline 4.1.1.18 & Lysine decarboxylase & $\begin{array}{l}\text { PFD0285c, } \\
\text { PFD0670c }\end{array}$ & $\begin{array}{c}\text { Lysine decarboxylase, } \\
\text { putative }\end{array}$ & $\begin{array}{l}\text { Polyamine } \\
\text { metabolism }\end{array}$ & - & - \\
\hline
\end{tabular}

micromolar level (Table 2) and reduces the parasitemia in Plasmodium berghei-infected mice [47, 48, 74, 75]. DFMO, a derivative of ornithine, inhibits the enzyme irreversibly by an alkylation of its active site. A combination of DFMO and bis(benzyl)polyamines revealed a curative effect in rodent malaria [76]. Moreover, DFMO reveals a more prominent role due to its effectiveness against Trypanosoma brucei gambiense, the agent of the West African Sleeping Sickness [77-79]. Only marginal effects of DFMO have been observed against the apicomplexan relatives of $P$. falciparum, Cryptosporidium sp. [80] and Toxoplasma gondii [50].

Furthermore, two decades ago, a series of potent ODC inhibitors were synthesized. These compounds belong to the group of 3-amino-oxy-1-propanamine (APA) [81, 82], such as CGP52622A and CGP54619A (Figure 2), which reversibly inhibit the PfODC with $\mathrm{IC}_{50}$-values at the nanomolar range (Table 3). APA itself had an $\mathrm{IC}_{50}$-value of $1 \mu \mathrm{M}$ revealing a 1000 -fold stronger antiplasmodial effect than DFMO ( $\mathrm{IC}_{50}$ value of $1.3 \mathrm{mM}$ ) (Table 3 ). However, APA and its analogues failed as drug candidates in the mouse model [83].

Another interesting PLP-mimicking compound is the cyclic pyridoxyl-tryptophan methyl ester PT3 which inhibits in its phosphorylated form (PPT3) the proliferation of $P$. falciparum at the cellular level ( $\mathrm{IC}_{50}$-value of $\left.14 \mu \mathrm{M}\right)$ without harming human cells [32]. Two further compounds of this chemical group, PPHME and PPT5, act as inhibitors of the plasmodial ODC with $\mathrm{IC}_{50}$-values of $58 \mu \mathrm{M}$ and $64 \mu \mathrm{M}$, respectively [32] (Figure 2). 
<smiles>COC(=O)C(Cc1c[nH]c2ccccc12)NCc1c(COP(=O)([O-])O)cnc(C)c1O</smiles>

PPT5<smiles>COC(=O)C1Cc2c([nH]c3ccccc23)[C@@H](c2c(O)cncc2COP(=O)(O)OC)N1</smiles>

PPT3<smiles>COC(=O)C(Cc1c[nH]cn1)NCc1c(COP(=O)(O)O)cnc(C)c1O</smiles>

PPHME<smiles>NCCCON</smiles><smiles>NCCC(N)(C(=O)O)C(F)F</smiles>

APA

DMFO<smiles>NOC1CCC(N)CC1</smiles><smiles>C[C@@H](N)CCON</smiles>

CGP 52622A

CGP 54169A

(a)

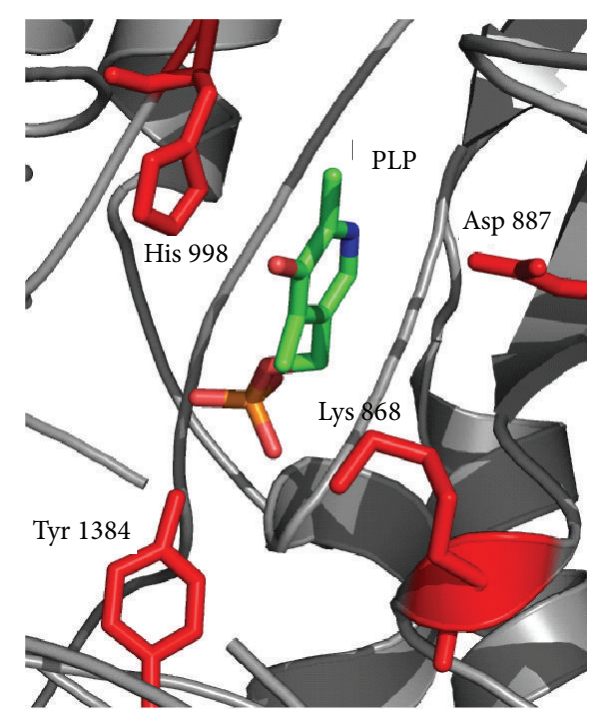

(b)

FIgURE 2: Comparison of the active site of the human and plasmodial ornithine decarboxylases (ODC). (a) Structures of ODC inhibitors tested against Plasmodium. (b) A structural homology model of the positions of the P. falciparum ODC active site (the respective residues are illustrated in red; amino acid numbering refers to the bifunctional protein) as well as the bound cofactor PLP.

\section{The $P$. falciparum Aspartate Aminotransferase (AspAT)}

Aspartate aminotransferases are involved in three different metabolic pathways. AspAT is responsible for the reversible catalysis of L-aspartate (Asp) into oxaloacetate (OAA) and $\alpha$ ketoglutarate (2OG) into L-glutamate (Glu) [37]. Bulusu and collaborators [84] highlighted that AspAT also acts together with the fumarate hydratase $(\mathrm{FH})$ and the malate-quinone oxidoreductase (MQO) in the conversion of fumarate to aspartate. The enzyme has also been described to accept $\alpha$-ketomethylthiobutyrate as substrate in order to generate methionine [85]. Like all other aminotransferases, AspAT is structurally classified as a PLP-dependent enzyme of the subgroup I as outlined previously (Table 1) [86].

In the malaria parasite, AspAT is localised in the cytosol and reveals a homodimeric structure with two joint active site regions formed by both subunits [87-89]. Special 

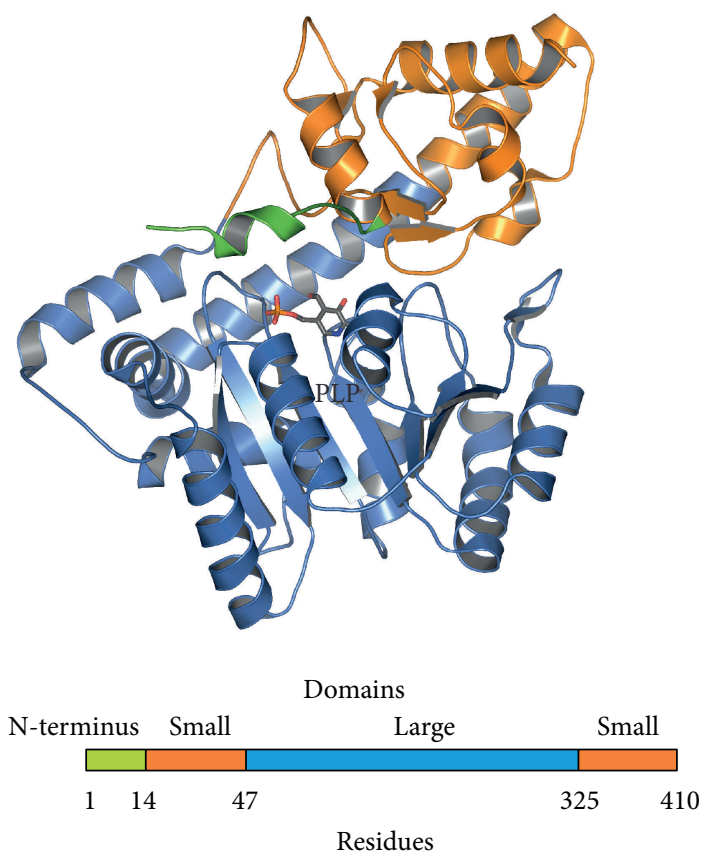

(a)

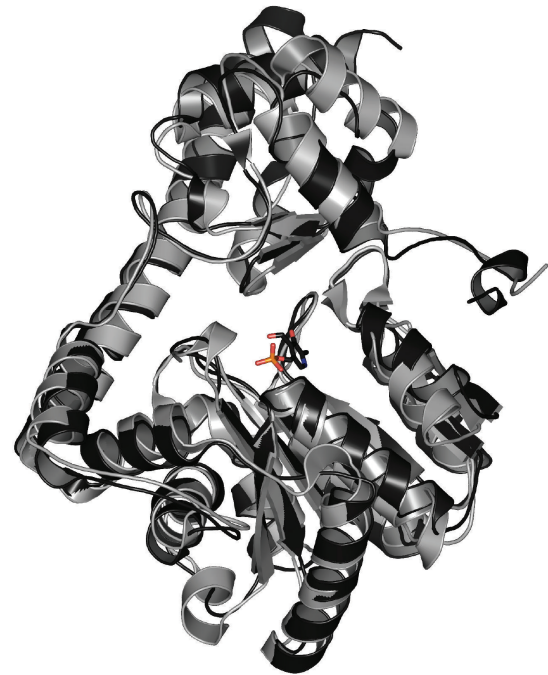

(b)

Figure 3: Three-dimensional structures of the AspATs. (a) The 3D structure of PfAspAT (PDB code: 3K7Y) highlighting the three major domains and the N-terminus (green) as additionally shown in the scheme below. (b) Comparison between the human AspAT (grey, PDB code: 3 HLM) and the P. falciparum counterpart (dark grey). The respective N-terminal region is illustrated in black and the cofactor PLP in colour.

TABLE 3: Comparison of the kinetic and inhibitory properties of ornithine decarboxylases.

\begin{tabular}{|c|c|c|c|c|c|}
\hline & P. falciparum ${ }^{*}$ & M. musculus & T. gondii & T. brucei & References \\
\hline Molecular mass (kDa) & 86.4 & $50-54$ & 14 & 90 & {$[41,46]$} \\
\hline$K_{m}$-value of L-ornithine $(\mu \mathrm{M})$ & 47.3 & $30-200$ & - & 161 & {$[41,47,48]$} \\
\hline$K_{i}$-value of putrescine $(\mu \mathrm{M})$ & 50.4 & 600 & 0.92 & - & {$[41,49]$} \\
\hline$K_{i}$-value of DFMO $(\mu \mathrm{M})$ & 87.6 & 39 & 0.025 & 220 & {$[41,50,51]$} \\
\hline$K_{i}$-value of CGP52622A (nM) & 20.4 & - & - & - & {$[41]$} \\
\hline$K_{i}$-value of CGP54619A (nM) & 7.9 & - & - & - & {$[41]$} \\
\hline $\mathrm{IC}_{50}$-value of putrescine $(\mu \mathrm{M})$ & 157 & - & - & - & {$[41]$} \\
\hline $\mathrm{IC}_{50}$-value of CGP52622A (nM) & 63.5 & 25 & - & - & {$[41]$} \\
\hline $\mathrm{IC}_{50}$-value of CGP54619A (nM) & 25 & 10 & - & - & {$[41]$} \\
\hline
\end{tabular}

${ }^{*}$ Data derived from the $\mathrm{r} P f$ hinge-ODC [41].

attention has been drawn on the plasmodial AspAT (PDB code $3 \mathrm{~K} 7 \mathrm{Y}$ ) which possesses a $\mathrm{N}$-terminal-extended region that is required for the dimerisation process (Figure 3) [37]. This was already used for binding of the N-terminal AspAT peptide to the N-terminal protein domain of the other PfAspAT monomer which prevents the formation of the homodimer. Interestingly, the plasmodial N-terminal region differs significantly from its human counterpart, so that the plasmodial peptide did not affect the human AspAT [37]. Furthermore, activity assays using P. falciparum protein extracts and the recombinantly expressed N-terminal PfAspAT peptide have been performed which prevented AspAT activity suggesting that the malaria parasite possesses no other enzyme that can compensate for the respective catalysis $[37,89]$.

\section{Serine Hydroxymethyltransferase (SHMT)}

As mentioned before, the folate metabolism in $P$. falciparum is a verified drug target and enzymatic reactions catalysed, for example, by the dihydrofolate reductase (DHFR) are already exploited by the classic antimalarials pyrimethamine and cycloguanil [90]. Another enzymatic step within the folate metabolism is carried out by the serine hydroxymethyltransferase (SHMT), catalysing the transfer of one-carbon units from serine to tetrahydrofolate to generate 5,10-methylene 


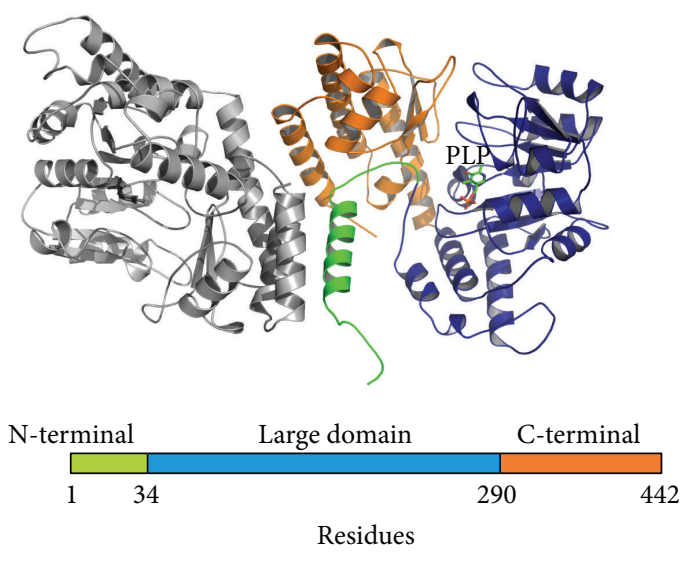

(a)<smiles>CC1(C)N=C(N)N=C(N)N1OCCCOc1cc(Cl)c(Cl)cc1Cl</smiles>

(c)

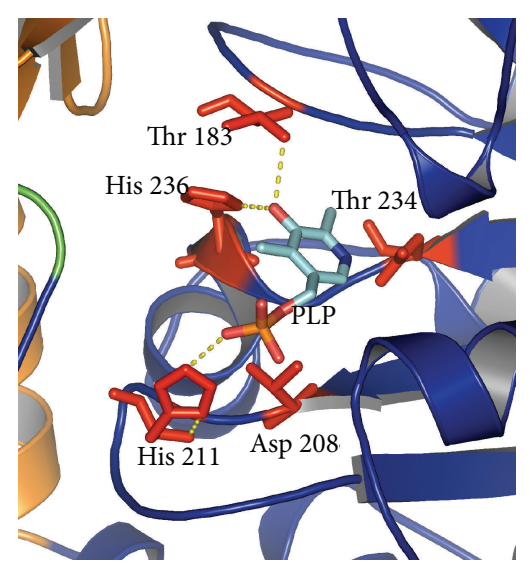

(b)

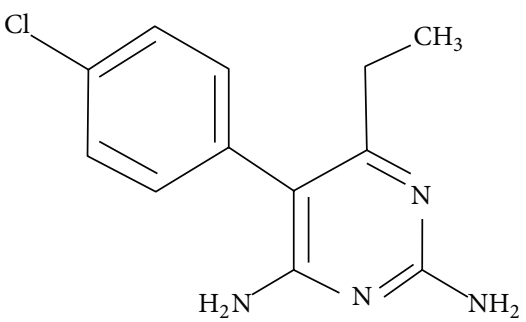

(d)

Figure 4: Model of the plasmodial SHMT and their active site residues. (a) Homology model of the SHMT of P. falciparum highlighting the three major domains: N-terminal (green), the core and active site (blue), and the C-terminal domain (orange). (b) The conserved residues Asp208, His211, Thr234, His236 and the Plasmodium-specific Thr183 residue are illustrated within the active site of the PfSHMT as well as its embedded cofactor. Chemical structures of validated inhibitors of the folate metabolism (c) WR99210 and (d) pyrimethamine.

tetrahydrofolate and glycine; this $\alpha$-elimination catalysis is PLP-dependent, thereby belonging to the subgroup I [91].

The folate metabolism is of particular interest because it is involved in the pyrimidine biosynthesis which is required for the DNA synthesis. Since the SHMT is part of the folate metabolism, its transcription profile is increased in the $S$ phase of the DNA replication [92]. Due to the importance of this enzyme, SHMT is considered as a potential drug target in cancer research $[93,94]$. In this sense, inhibitors against tumour cells have already been developed, which are intended to mimic nucleosides in order to be subsequently incorporated into the DNA, thereby leading to its fragmentation [95]. The SHMT of P. falciparum has been analysed for its functionality by complementation assays in Escherichia coli [96]. Moreover, activity assays using the recombinantly expressed PfSHMT showed that the enzyme accepts in addition to the natural substrate-unlike its mammal counterpart-D-serine. This lack of stereospecificity has also been observed for the respective $P$. vivax enzyme [97]. Further, the plasmodial enzyme can be also inhibited competitively by glycine and serine [34].

Since the substrates of SHMT and DHFR are structurally similar (Figure 4), pyrimethamine, a potent inhibitor of the plasmodial DHFR, has also been tested on the recombinant SHMT, however, only with a marginal effect $\left(\mathrm{IC}_{50}\right.$-value in the midmicromolar range) [35]. The comparison between the active site of the human enzyme and the plasmodial one showed a high degree of similarity as illustrated in Figure 4 [98], but, in contrast to the mammalian SHMT, which reveals a homotetrameric structure, the structural conformation of the plasmodial protein pointed towards a homodimeric appearance due to the lack of amino acid residues proposed to be involved in tetramerisation (like the His 135 and a poly-K sequence within the N-terminal domain) [98].

Despite all the similarities between the human and the malaria SHMT, the plasmodial enzyme possesses some peculiarities in the regulation of the folate metabolism such as binding to its own RNA [35], thus inhibiting protein translation [99].

Recently, a second open reading frame encoding for a potential mitochondrial SHMT (PF14_0534, mSHMT) has been identified in $P$. falciparum. However, in comparison to other SHMTs, the active site of the plasmodial mSHMT does not reveal preserved amino acid residues $[35,100]$.

\section{Druggable PLP-Dependent Enzymes in the Malaria Vector}

Within the life cycle of $P$. falciparum, the necessity of PLPdependent enzymes is not only restricted to the parasite. In 
order to complete its life cycle, sexual forms of the parasite have to be taken up via the blood meal of the Anopheles vector to enter the mosquito gut [3]. Subsequently, the gametogenesis is induced in the mosquito stage by Anopheles derived triggers [101]. One of these molecules, that has been described to play a role in this event, is xanthurenic acid (XA) [101]. XA is generated by a transamination reaction of 3-hydroxykynurenine (3-HK) which is catalysed by the PLP-dependent A. gambiae 3-HK transaminase (AgHKT), an enzyme classified to the subgroup I. This reaction is necessary to prevent accumulation of the 3-HK, which can become a toxic molecule if it undergoes spontaneous oxidation and thereby generates ROS $[45,101]$. The threedimensional structure of the recombinant $A g H K T$ was solved as a homodimer with a PLP molecule located in its active site $[58,86]$. Currently, there are no inhibitors known to target the $A g \mathrm{HKT}$, although structural information would enable in silico based drug-design [45]. Selective interference with the mosquito HKT would prevent the synthesis of XA and thereby offers the opportunity to block the life cycle of the malaria parasite in the mosquito stage.

\section{Conclusion}

Although the mortality of malaria infections is declining, the disease, of which malaria tropica (caused by $P$. falciparum) is the most fatal form, belongs still to the most important infectious disease to man. Due to the increasing level of resistance against the current chemotherapeutics, there is an urgent need to discover novel drugs which should have the ability to selectively interfere with the proliferation of this human pathogen. In this sense, the unique plasmodial cofactor metabolism becomes an attractive drug target due to the variety of cofactor-dependent enzymes. In particular, PLP-dependent enzymes are widely distributed in the metabolism of $P$. falciparum and responsible for plenty of essential catalyses such as the reactions carried out by the ODC, AspAT, or SHMT as outlined in this minireview. Hence, drug discovery towards inhibition of cofactor-binding would not only target single enzymes; moreover, the entire family of PLP-dependent proteins would be affected. This would certainly lead to the death of the parasite. However, the respective PLP-dependent host enzymes have to be taken into account. Therefore, the selective impairment of the malaria specific vitamin B6 biosynthesis should be considered.

\section{Conflict of Interests}

The authors declare that there is no conflict of interests regarding the publication of this paper.

\section{Authors' Contribution}

Thales Kronenberger, Jasmin Lindner, Kamila A. Meissner, and Flávia M. Zimbres contributed equally to this work.

\section{Acknowledgments}

This work was financially supported by the Grants nos. 2009/54325-2, 2010/20647-0, 2011/13706-3, 2011/19703-6,
2012/12807-3, 2012/12790-3, and 2013/10288-1 from the Fundação de Amparo a Pesquisa do Estado de São Paulo (FAPESP). The authors would also like to acknowledge the CAPES/DAAD support within the UNIBRAL Programme entitled "INFECTBIO-USP-WWU" (348/2013).

\section{References}

[1] (WHO), WHO, Geneva, Switzerland, 2011.

[2] S. Sabbatani, S. Fiorino, and R. Manfredi, "The emerging of the fifth malaria parasite (Plasmodium Knowlesi). A public health concern?" Brazilian Journal of Infectious Diseases, vol. 14, no. 3, pp. 299-309, 2010.

[3] B. M. Greenwood, D. A. Fidock, D. E. Kyle et al., "Malaria: progress, perils, and prospects for eradication," Journal of Clinical Investigation, vol. 118, no. 4, pp. 1266-1276, 2008.

[4] J. M. Cohen, D. L. Smith, C. Cotter et al., "Malaria resurgence: a systematic review and assessment of its causes," Malaria Journal, vol. 11, article 122, 2012.

[5] D. G. Heppner, “The malaria vaccine-status quo 2013," Travel Medicine and Infectious Disease, vol. 11, pp. 2-7, 2013.

[6] E. M. Riley and V. A. Stewart, "Immune mechanisms in malaria: new insights in vaccine development," Nature Medicine, vol. 19, pp. 168-178, 2013.

[7] T. Kronenberger, I. Schettert, and C. Wrenger, "Targeting the vitamin biosynthesis pathways for the treatment of malaria," Future Medicinal Chemistry, vol. 5, no. 7, pp. 769-779, 2013.

[8] A. Nzila, S. A. Ward, K. Marsh, P. F. G. Sims, and J. E. Hyde, "Comparative folate metabolism in humans and malaria parasites (part I): pointers for malaria treatment from cancer chemotherapy," Trends in Parasitology, vol. 21, no. 6, pp. 292298, 2005.

[9] J. N. Burrows, "Antimalarial drug discovery: where next?" Future Medicinal Chemistry, vol. 4, no. 18, pp. 2233-2235, 2012.

[10] A. Bhattarai, A. S. Ali, S. P. Kachur et al., "Impact of artemisininbased combination therapy and insecticide-treated nets on malaria burden in Zanzibar," PLoS Medicine, vol. 4, no. 11, article e309, 2007.

[11] P. Olliaro, "Mode of action and mechanisms of resistance for antimalarial drugs," Pharmacology and Therapeutics, vol. 89, no. 2, pp. 207-219, 2001.

[12] I. B. Müller and J. E. Hyde, "Antimalarial drugs: modes of action and mechanisms of parasite resistance," Future Microbiology, vol. 5, no. 12, pp. 1857-1873, 2010.

[13] I. B. Müller, J. E. Hyde, and C. Wrenger, "Vitamin B metabolism in Plasmodium falciparum as a source of drug targets," Trends in Parasitology, vol. 26, no. 1, pp. 35-43, 2010.

[14] W. Friedrich, Vitamins, Walter de Gruyter, Berlin, Germany, 1988.

[15] R. Percudani and A. Peracchi, "A genomic overview of pyridoxal-phosphate-dependent enzymes," EMBO Reports, vol. 4, no. 9, pp. 850-854, 2003.

[16] T. B. Fitzpatrick, N. Amrhein, B. Kappes, P. Macheroux, I. Tews, and T. Raschle, "Two independent routes of de novo vitamin B6 biosynthesis: not that different after all," Biochemical Journal, vol. 407, no. 1, pp. 1-13, 2007.

[17] H. M. Lam, E. Tancula, W. B. Dempsey, and M. E. Winkler, "Suppression of insertions in the complex pdxJ operon of Escherichia coli K-12 by lon and other mutations," Journal of Bacteriology, vol. 174, no. 5, pp. 1554-1567, 1992. 
[18] B. B. Roa, D. M. Connolly, and M. E. Winkler, "Overlap between pdxA and ksgA in the complex pdxA-ksgA-apaG-apaH operon of Escherichia coli K-12," Journal of Bacteriology, vol. 171, no. 9, pp. 4767-4777, 1989.

[19] J. Knöckel, I. B. Müller, B. Bergmann, R. D. Walter, and C. Wrenger, "The apicomplexan parasite Toxoplasma gondii generates pyridoxal phosphate de novo," Molecular and Biochemical Parasitology, vol. 152, no. 1, pp. 108-111, 2007.

[20] C. Wrenger, M. Eschbach, I. B. Müller, D. Warnecke, and R. D. Walter, "Analysis of the vitamin B6 biosynthesis pathway in the human malaria parasite Plasmodium falciparum," The Journal of Biological Chemistry, vol. 280, no. 7, pp. 5242-5248, 2005.

[21] M. Gengenbacher, T. B. Fitzpatrick, T. Raschle et al., "Vitamin B6 biosynthesis by the malaria parasite Plasmodium falciparum: biochemical and structural insights," The Journal of Biological Chemistry, vol. 281, no. 6, pp. 3633-3641, 2006.

[22] M. Ehrenshaft, P. Bilski, M. Li, C. F. Chignell, and M. E. Daub, "A highly conserved sequence is a novel gene involved in de novo vitamin B6 biosynthesis," Proceedings of the National Academy of Sciences of the United States of America, vol. 96, no. 16, pp. 9374-9378, 1999.

[23] M. Ehrenshaft, A. E. Jenns, K. R. Chung, and M. E. Daub, "SOR1, a gene required for photosensitizer and singlet oxygen resistance in Cercospora fungi, is highly conserved in divergent organisms," Molecular Cell, vol. 1, no. 4, pp. 603-609, 1998.

[24] M. Strohmeier, T. Raschle, J. Mazurkiewicz et al., "Structure of a bacterial pyridoxal 5 '-phosphate synthase complex," Proceedings of the National Academy of Sciences of the United States of America, vol. 103, no. 51, pp. 19284-19289, 2006.

[25] J. Zhu, J. W. Burgner, E. Harms, B. R. Belitsky, and J. L. Smith, "A new arrangement of $(\beta / \alpha) 8$ barrels in the synthase subunit of PLP synthase," The Journal of Biological Chemistry, vol. 280, no. 30, pp. 27914-27923, 2005.

[26] I. B. Müller, J. Knöckel, M. R. Groves et al., "The assembly of the plasmodial PLP synthase complex follows a defined course," PLoS ONE, vol. 3, no. 3, Article ID e1815, 2008.

[27] S. B. Reeksting, I. B. Müler, P. B. Burger et al., "Exploring inhibition of Pdxl, a component of the PLP synthase complex of the human malaria parasite Plasmodium falciparum," Biochemical Journal, vol. 449, no. 1, pp. 175-187, 2013.

[28] J. Knöckel, I. B. Müller, S. Butzloff, B. Bergmann, R. D. Walter, and C. Wrenger, "The antioxidative effect of de novo generated vitamin B6 in Plasmodium falciparum validated by protein interference," Biochemical Journal, vol. 443, no. 2, pp. 397-405, 2012.

[29] K. Becker, L. Tilley, J. L. Vennerstrom, D. Roberts, S. Rogerson, and H. Ginsburg, "Oxidative stress in malaria parasite-infected erythrocytes: host-parasite interactions," International Journal for Parasitology, vol. 34, no. 2, pp. 163-189, 2004.

[30] S. Müller, "Redox and antioxidant systems of the malaria parasite Plasmodium falciparum," Molecular Microbiology, vol. 53, no. 5, pp. 1291-1305, 2004.

[31] J. Knöckel, B. Bergmann, I. B. Müller, S. Rathaur, R. D. Walter, and C. Wrenger, "Filling the gap of intracellular dephosphorylation in the Plasmodium falciparum vitamin B1 biosynthesis," Molecular and Biochemical Parasitology, vol. 157, no. 2, pp. 241243, 2008.

[32] I. B. Müller, F. Wu, B. Bergmann et al., "Poisoning pyridoxal 5-phosphate-dependent enzymes: a new strategy to target the malaria parasite Plasmodium falciparum," PLoS ONE, vol. 4, no. 2, Article ID e4406, 2009.
[33] A. Amadasi, M. Bertoldi, R. Contestabile et al., "Pyridoxal 5' phosphate enzymes as targets for therapeutic agents," Current Medicinal Chemistry, vol. 14, no. 12, pp. 1291-1324, 2007.

[34] S. Maenpuen, K. Sopitthummakhun, Y. Yuthavong, P. Chaiyen, and U. Leartsakulpanich, "Characterization of Plasmodium falciparum serine hydroxymethyltransferase-a potential antimalarial target," Molecular and Biochemical Parasitology, vol. 168, no. 1, pp. 63-73, 2009.

[35] C. K. T. Pang, J. H. Hunter, R. Gujjar et al., "Catalytic and ligand-binding characteristics of Plasmodium falciparum serine hydroxymethyltransferase," Molecular and Biochemical Parasitology, vol. 168, no. 1, pp. 74-83, 2009.

[36] S. Varadharajan, S. Dhanasekaran, Z. Q. Bonday, P. N. Rangarajan, and G. Padmanaban, "Involvement of $\delta$-aminolaevulinate synthase encoded by the parasite gene in de novo haem synthesis by Plasmodium falciparum," Biochemical Journal, vol. 367, no. 2, pp. 321-327, 2002.

[37] C. Wrenger, I. B. Müller, A. J. Schifferdecker, R. Jain, R. Jordanova, and M. R. Groves, "Specific inhibition of the aspartate aminotransferase of Plasmodium falciparum," Journal of Molecular Biology, vol. 405, no. 4, pp. 956-971, 2011.

[38] C. Gafan, J. Wilson, L. C. Berger, and B. J. Berger, "Characterization of the ornithine aminotransferase from Plasmodium falciparum," Molecular and Biochemical Parasitology, vol. 118, no. 1, pp. 1-10, 2001.

[39] L. Birkholtz, F. Joubert, A. W. H. Neitz, and A. I. Louw, "Comparative properties of a three-dimensional model of Plasmodium falciparum ornithine decarboxylase," Proteins, vol. 50, no. 3, pp. 464-473, 2003.

[40] L. M. Birkholtz, C. Wrenger, F. Joubert, G. A. Wells, R. D. Walter, and A. I. Louw, "Parasite-specific inserts in the bifunctional S-adenosylmethionine decarboxylase/ornithine decarboxylase of Plasmodium falciparum modulate catalytic activities and domain interactions," Biochemical Journal, vol. 377, no. 2, pp. 439-448, 2004.

[41] T. Krause, K. Lüersen, C. Wrenger, T. W. Gilberger, S. Müller, and R. D. Walter, "The ornithine decarboxylase domain of the bifunctional ornithine decarboxylase/S-adenosylmethionine decarboxylase of Plasmodium falciparum: recombinant expression and catalytic properties of two different constructs," Biochemical Journal, vol. 352, no. 2, pp. 287-292, 2000.

[42] C. Wrenger, K. Lüersen, T. Krause, S. Müller, and R. D. Walter, "The Plasmodium falciparum bifunctional ornithine decarboxylase, S-adenosyl-L-methionine decarboxylase, enables a well balanced polyamine synthesis without domain-domain interaction," The Journal of Biological Chemistry, vol. 276, no. 32, pp. 29651-29656, 2001.

[43] A. C. van Brumelen, K. L. Olszewski, D. Willinski, M. Llinás, A. I. Louw, and L. Birkholtz, "Co-inhibition of Plasmodium falciparum S-Adenosylmethionine decarboxylase/ornithine decarboxylase reveals perturbation-specific compensatory mechanisms by transcriptome, proteome, and metabolome analyses," The Journal of Biological Chemistry, vol. 284, no. 7, pp. 46354646, 2009.

[44] M. Williams, J. Sprenger, E. Human et al., "Biochemical characterisation and novel classification of monofunctional Sadenosylmethionine decarboxylase of Plasmodium falciparum," Molecular and Biochemical Parasitology, vol. 180, no. 1, pp. 1726, 2011.

[45] F. Rossi, S. Garavaglia, G. B. Giovenzana, B. Arcà, J. Li, and M. Rizzi, "Crystal structure of the Anopheles gambiae 3hydroxykynurenine transaminase," Proceedings of the National 
Academy of Sciences of the United States of America, vol. 103, no. 15, pp. 5711-5716, 2006.

[46] M. A. Phillips, P. Coffino, and C. C. Wang, "Trypanosoma brucei ornithine decarboxylase: enzyme purification, characterization, and expression in Escherichia coli," The Journal of Biological Chemistry, vol. 263, no. 34, pp. 17933-17941, 1988.

[47] Y. G. Assaraf, J. Golenser, D. T. Spira, and U. Bachrach, "Polyamine levels and the activity of their biosynthetic enzymes in human erythrocytes infected with the malarial parasite, Plasmodium falciparum," Biochemical Journal, vol. 222, no. 3, pp. 815-819, 1984.

[48] Y. G. Assaraf, C. Kahana, D. T. Spira, and U. Bachrach, "Plasmodium falciparum: purification, properties, and immunochemical study of ornithine decarboxylase, the key enzyme in polyamine biosynthesis," Experimental Parasitology, vol. 67, no. 1, pp. 20-30, 1988.

[49] S. H. Seabra, R. A. DaMatta, F. G. de Mello, and W. de Souza, "Endogenous polyamine levels in macrophages is sufficient to support growth of Toxoplasma gondii," Journal of Parasitology, vol. 90 , no. 3, pp. 455-460, 2004.

[50] F. Derouin and C. Chastang, "Enzyme immunoassay to assess effect of antimicrobial agents on Toxoplasma gondii in tissue culture," Antimicrobial Agents and Chemotherapy, vol. 32, no. 3, pp. 303-307, 1988.

[51] M. Dixon and E. C. Webb, Enzymes, Academic Press, New York, NY, USA, 1979.

[52] S. D. Copley, "Enzymes with extra talents: moonlighting functions and catalytic promiscuity," Current Opinion in Chemical Biology, vol. 7, no. 2, pp. 265-272, 2003.

[53] R. A. John, "Pyridoxal phosphate-dependent enzymes," Biochimica et Biophysica Acta, vol. 1248, no. 2, pp. 81-96, 1995.

[54] A. J. Romo and H. W. Liu, "Mechanisms and structures of vitamin B6-dependent enzymes involved in deoxy sugar biosynthesis," Biochimica et Biophysica Acta, vol. 1814, no. 11, pp. 1534-1547, 2011.

[55] D. Palm, H. W. Klein, R. Schinzel, M. Buehner, and E. J. M. Helmreich, "The role of pyridoxal $5^{\prime}$-phosphate in glycogen phosphorylase catalysis," Biochemistry, vol. 29, no. 5, pp. 1099$1107,1990$.

[56] J. F. Kirsch, G. Eichele, G. C. Ford et al., "Mechanism of action of aspartate aminotransferase proposed on the basis of its spatial structure," Journal of Molecular Biology, vol. 174, no. 3, pp. 497$525,1984$.

[57] P. K. Mehta and P. Christen, "The molecular evolution of pyridoxal-5'-phosphate-dependent enzymes," Advances in Enzymology and Related Areas of Molecular Biology, vol. 74, pp. 129-184, 2000.

[58] P. Christen and P. K. Mehta, "From cofactor to enzymes. The molecular evolution of pyridoxal-5' -pliosphate-dependent enzymes," Chemical Records, vol. 1, no. 6, pp. 436-447, 2001.

[59] B. Kappes, I. Tews, A. Binter, and P. Macheroux, "PLPdependent enzymes as potential drug targets for protozoan diseases," Biochimica et Biophysica Acta, vol. 1814, no. 11, pp. 1567-1576, 2011.

[60] P. Storici, D. de Biase, F. Bossa et al., "Structures of $\gamma$ aminobutyric acid (GABA) aminotransferase, a pyridoxal $5^{\prime}$ phosphate, and [2Fe-2S] cluster-containing enzyme, complexed with $\gamma$-ethynyl-GABA and with the antiepilepsy drug vigabatrin," The Journal of Biological Chemistry, vol. 279, no. 1, pp. 363$373,2004$.
[61] G. F. Stamper, A. A. Morollo, and D. Ringe, "Reaction of alanine racemase with 1-aminoethylphosphonic acid forms a stable external aldimine," Biochemistry, vol. 29, no. 20, pp. 1043810445, 1998.

[62] F. Wu and H. Gehring, "Structural requirements for novel coenzyme-substrate derivatives to inhibit intracellular ornithine decarboxylase and cell proliferation," FASEB Journal, vol. 23, no. 2, pp. 565-574, 2009.

[63] C. W. Tabor and H. Tabor, "Polyamines", Annual Review of Biochemistry, vol. 53, pp. 749-790, 1983.

[64] C. W. Tabor and H. Tabor, "Polyamines in microorganisms," Microbiological Reviews, vol. 49, no. 1, pp. 81-99, 1985.

[65] H. M. Wallace, A. V. Fraser, and A. Hughes, "A perspective of polyamine metabolism," Biochemical Journal, vol. 376, no. 1, pp. $1-14,2003$.

[66] S. Müller, A. Da'dara, K. Lüersen et al., "In the human malaria parasite Plasmodium falciparum, polyamines are synthesized by a bifunctional ornithine decarboxylase, S-adenosylmethionine decarboxylase," The Journal of Biological Chemistry, vol. 275, no. 11, pp. 8097-8102, 2000.

[67] K. M. Ivanetich and D. V. Santi, "Bifunctional thymidylate synthase-dihydrofolate reductase in protozoa," FASEB Journal, vol. 4, no. 6, pp. 1591-1597, 1990.

[68] D. J. Bzik, W. B. Li, T. Horii, and J. Inselburg, "Molecular cloning and sequence analysis of the Plasmodium falciparum dihydrofolate reductase-thymidylate synthase gene," Proceedings of the National Academy of Sciences of the United States of America, vol. 84, no. 23, pp. 8360-8364, 1987.

[69] T. Triglia and A. F. Cowman, "Primary structure and expression of the dihydropteroate synthetase gene of Plasmodium falciparum," Proceedings of the National Academy of Sciences of the United States of America, vol. 91, no. 15, pp. 7149-7153, 1994.

[70] J. L. Clarke, D. A. Scopes, O. Sodeinde, and P. J. Mason, "Glucose-6-phosphate dehydrogenase-6-phosphogluconolactonase: a novel bifunctional enzyme in malaria parasites," European Journal of Biochemistry, vol. 268, no. 7, pp. 2013-2019, 2001.

[71] D. J. Carucci, A. A. Witney, D. K. Muhia et al., "Guanylyl cyclase activity associated with putative bifunctional integral membrane proteins in Plasmodium falciparum," The Journal of Biological Chemistry, vol. 275, no. 29, pp. 22147-22156, 2000.

[72] I. B. Müller, R. Das Gupta, K. Lüersen, C. Wrenger, and R. D. Walter, "Assessing the polyamine metabolism of Plasmodium falciparum as chemotherapeutic target," Molecular and Biochemical Parasitology, vol. 160, no. 1, pp. 1-7, 2008.

[73] J. S. Heller, E. S. Canellakis, D. L. Bussolotti, and J. K. Coward, "Stable multisubstrate adducts as enzyme inhibitors. Potent inhibition of ornithine decarboxylase by $\mathrm{N}\left(5^{\prime}\right.$ phosphopyridoxyl) ornithine," Biochimica et Biophysica Acta, vol. 403, no. 1, pp. 197-207, 1975.

[74] A. J. Bitonti, P. P. McCann, and A. Sjoerdsma, "Plasmodium falciparum and Plasmodium berghei: effects of ornithine decarboxylase inhibitors on erythrocytic schizogony," Experimental Parasitology, vol. 64, no. 2, pp. 237-243, 1987.

[75] M. R. Hollingdale, P. P. McCann, and A. Sjoerdsma, "Plasmodium berghei: inhibitors of ornithine decarboxylase block exoerythrocytic schizogony," Experimental Parasitology, vol. 60, no. 1, pp. 111-117, 1985.

[76] A. J. Bitonti, J. A. Dumont, T. L. Bush et al., "Bis(benzyl)polyamine analogs inhibit the growth of chloroquine-resistant human malaria parasites (Plasmodium falciparum) in vitro and 
in combination with $\alpha$-difluoromethylornithine cure murine malaria," Proceedings of the National Academy of Sciences of the United States of America, vol. 86, no. 2, pp. 651-655, 1989.

[77] C. J. Bacchi, H. C. Nathan, S. H. Hutner, P. P. McCann, and A. Sjoerdsma, "Polyamine metabolism: a potential therapeutic target in trypanosomes," Science, vol. 210, no. 4467, pp. 332-334, 1980.

[78] C. Burri and R. Brun, "Eflornithine for the treatment of human African trypanosomiasis," Parasitology Research, vol. 90, supplement 1, pp. S49-S52, 2003.

[79] A. Sjoerdsma and P. J. Schechter, "Eflornithine for African sleeping sickness," The Lancet, vol. 354, no. 9174, p. 254, 1999.

[80] H. W. Moon, A. Schwartz, M. J. Welch, P. P. McCann, and P. L. Runnels, "Experimental fecal transmission of human cryptosporidia to pigs, and attempted treatment with an ornithine decarboxylase inhibitor," Veterinary Pathology, vol. 19, no. 6, pp. 700-707, 1982.

[81] H. Mett, J. Stanek, J. A. Lopez-Ballester et al., "Pharmacological properties of the ornithine decarboxylase inhibitor 3aminooxy-1-propanamine and several structural analogues," Cancer Chemotherapy and Pharmacology, vol. 32, pp. 39-45, 1993.

[82] J. Stanek, J. Frei, H. Mett, P. Schneider, and U. Regenass, "2-Substituted 3-(aminooxy)propanamines as inhibitors of ornithine decarboxylase: synthesis and biological activity," Journal of Medicinal Chemistry, vol. 35, no. 8, pp. 1339-1344, 1992.

[83] R. Das Gupta, T. Krause-Ihle, B. Bergmann et al., "3-Aminooxy1-aminopropane and derivatives have an antiproliferative effect on cultured Plasmodium falciparum by decreasing intracellular polyamine concentrations," Antimicrobial Agents and Chemotherapy, vol. 49, no. 7, pp. 2857-2864, 2005.

[84] V. Bulusu, V. Jayaraman, and H. Balaram, "Metabolic fate of fumarate, a side product of the purine salvage pathway in the intraerythrocytic stages of Plasmodium falciparum," The Journal of Biological Chemistry, vol. 286, no. 11, pp. 9236-9245, 2011.

[85] L. C. Berger, J. Wilson, P. Wood, and B. J. Berger, "Methionine regeneration and aspartate aminotransferase in prasitic protozoa," Journal of Bacteriology, vol. 183, no. 15, pp. 4421-4434, 2001.

[86] P. K. Mehta, T. I. Hale, and P. Christen, "Aminotransferases: demonstration of homology and division into evolutionary subgroups," European Journal of Biochemistry, vol. 214, no. 2, pp. 549-561, 1993.

[87] R. Jain, R. Jordanova, I. B. Müller, C. Wrenger, and M. R. Groves, "Purification, crystallization and preliminary X-ray analysis of the aspartate aminotransferase of Plasmodium falciparum," Acta Crystallographica F, vol. 66, no. 4, pp. 409-412, 2010.

[88] D. Liu, E. Pozharski, B. W. Lepore et al., "Inactivation of Escherichia coli L-aspartate aminotransferase by (S)-4-amino4,5-dihydro-2-thiophenecarboxylic acid reveals 'A tale of two mechanisms," Biochemistry, vol. 46, no. 37, pp. 10517-10527, 2007.

[89] C. Wrenger, I. B. Müller, A. M. Silber, R. Jordanova, V. S. Lamzin, and M. R. Groves, "Aspartate aminotransferasebridging carbohydrate and energy metabolism in Plasmodium falciparum," Current Drug Metabolism, vol. 13, no. 3, pp. 332336, 2012.

[90] A. Nzila, "The past, present and future of antifolates in the treatment of Plasmodium falciparum infection," Journal of Antimicrobial Chemotherapy, vol. 57, no. 6, pp. 1043-1054, 2006.
[91] V. Schirch and D. M. E. Szebenyi, "Serine hydroxymethyltransferase revisited," Current Opinion in Chemical Biology, vol. 9, no. 5, pp. 482-487, 2005.

[92] N. Nirmalan, P. Wang, P. F. G. Sims, and J. E. Hyde, “Transcriptional analysis of genes encoding enzymes of the folate pathway in the human malaria parasite Plasmodium falciparum," Molecular Microbiology, vol. 46, no. 1, pp. 179-190, 2002.

[93] S. Agrawal, A. Kumar, V. Srivastava, and B. N. Mishra, "Cloning, expression, activity and folding studies of serine hydroxymethyltransferase: a target enzyme for cancer chemotherapy," Journal of Molecular Microbiology and Biotechnology, vol. 6, no. 2, pp. 67-75, 2003.

[94] H. G. Eichler, R. Hubbard, and K. Snell, "The role of serine hydroxymethyltransferase in cell proliferation: DNA synthesis from serine following mitogenic stimulation of lymphocytes," Bioscience Reports, vol. 1, no. 2, pp. 101-106, 1981.

[95] A. Yoshioka, S. Tanaka, O. Hiraoka et al., "Deoxyribonucleoside triphosphate imbalance. 5-fluorodeoxyuridine-induced DNA double strand breaks in mouse FM3A cells and the mechanism of cell death," The Journal of Biological Chemistry, vol. 262, no. 17, pp. 8235-8241, 1987.

[96] S. Alfadhli and P. K. Rathod, "Gene organization of a Plasmodium falciparum serine hydroxymethyltransferase and its functional expression in Escherichia coli," Molecular and Biochemical Parasitology, vol. 110, no. 2, pp. 283-291, 2000.

[97] K. Sopitthummakhun, S. Maenpuen, Y. Yuthavong, U. Leartsakulpanich, and P. Chaiyen, "Serine hydroxymethyltransferase from Plasmodium vivax is different in substrate specificity from its homologues," FEBS Journal, vol. 276, no. 15, pp. 4023-4036, 2009.

[98] T. C. França, P. G. Pascutti, T. C. Ramalho, and J. D. Figueroa-Villar, "A three-dimensional structure of Plasmodium falciparum serine hydroxymethyltransferase in complex with glycine and 5-formyl-tetrahydrofolate. Homology modeling and molecular dynamics," Biophysical Chemistry, vol. 115, no. 1, pp. 1-10, 2005.

[99] E. Chu, C. H. Takimoto, D. Voeller, J. L. Grem, and C. J. Allegra, "Specific binding of human dihydrofolate reductase protein to Dihydrofolate reductase messenger RNA in vitro," Biochemistry, vol. 32, no. 18, pp. 4756-4760, 1993.

[100] E. Salcedo, P. F. G. Sims, and J. E. Hyde, "A glycine-cleavage complex as part of the folate one-carbon metabolism of Plasmodium falciparum," Trends in Parasitology, vol. 21, no. 9, pp. 406-411, 2005.

[101] G. E. Garcia, R. A. Wirtz, J. R. Barr, A. Woolfitt, and R. Rosenbergt, "Xanthurenic acid induces gametogenesis in Plasmodium, the malaria parasite," The Journal of Biological Chemistry, vol. 273, no. 20, pp. 12003-12005, 1998. 

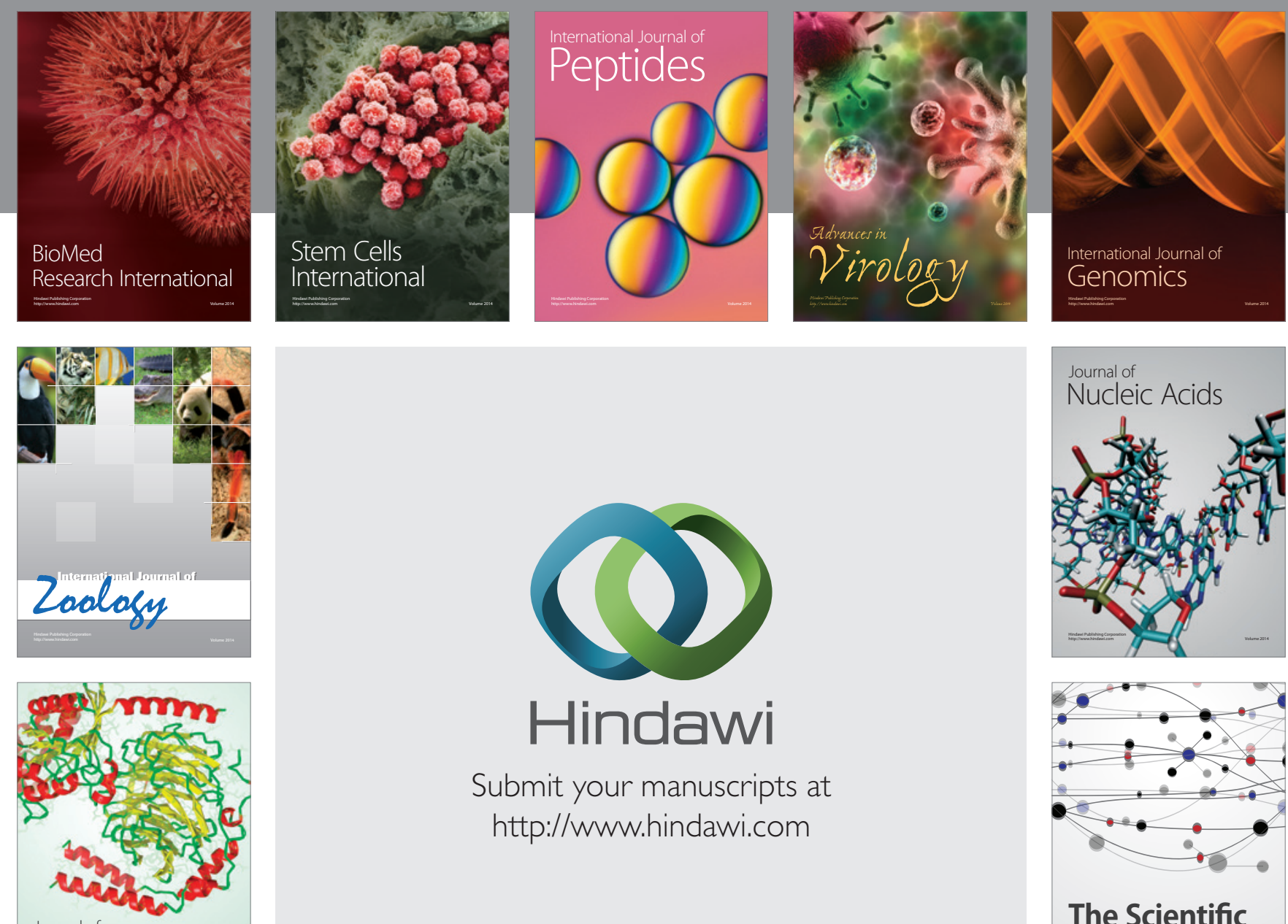

Submit your manuscripts at

http://www.hindawi.com

Journal of
Signal Transduction
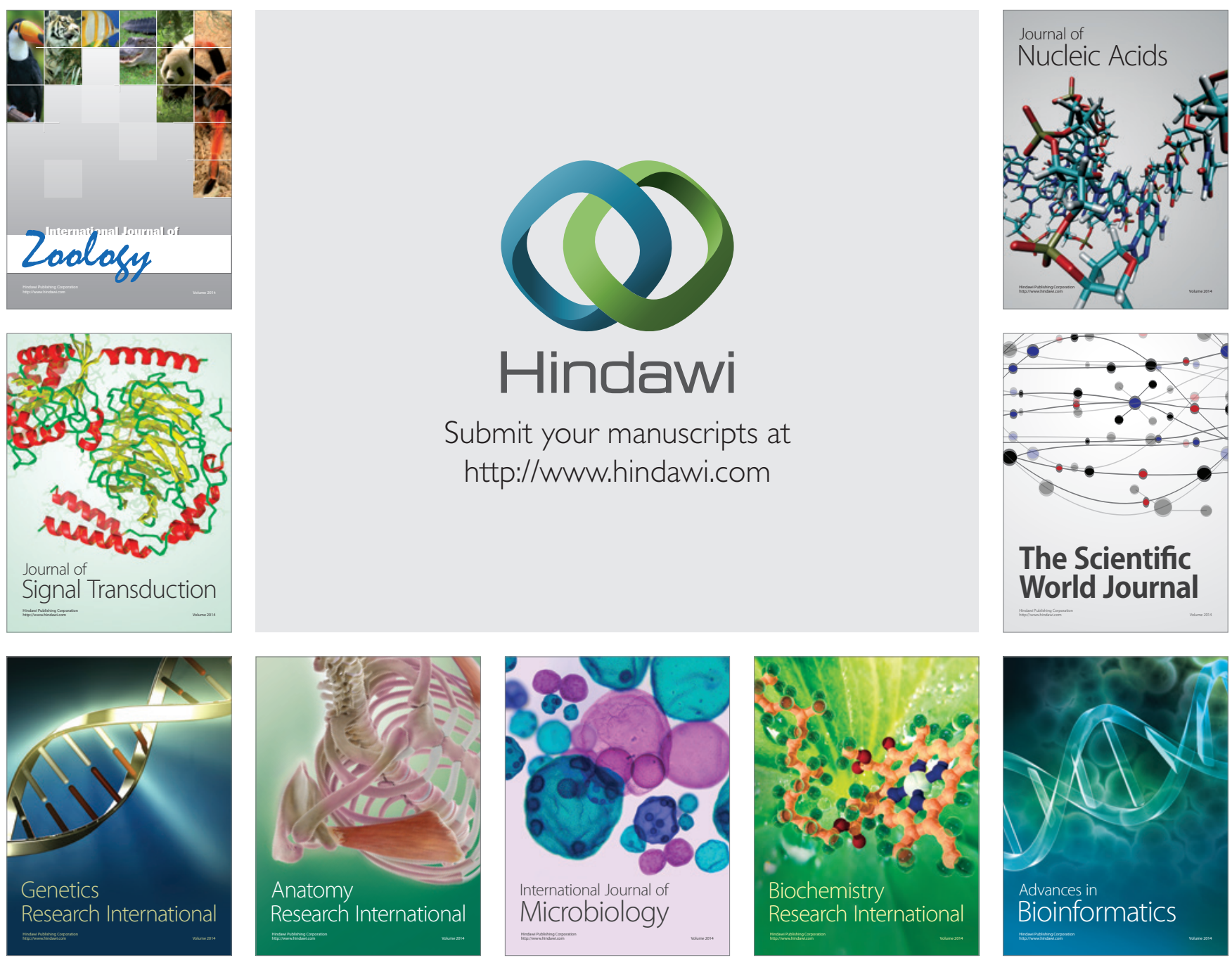

The Scientific World Journal
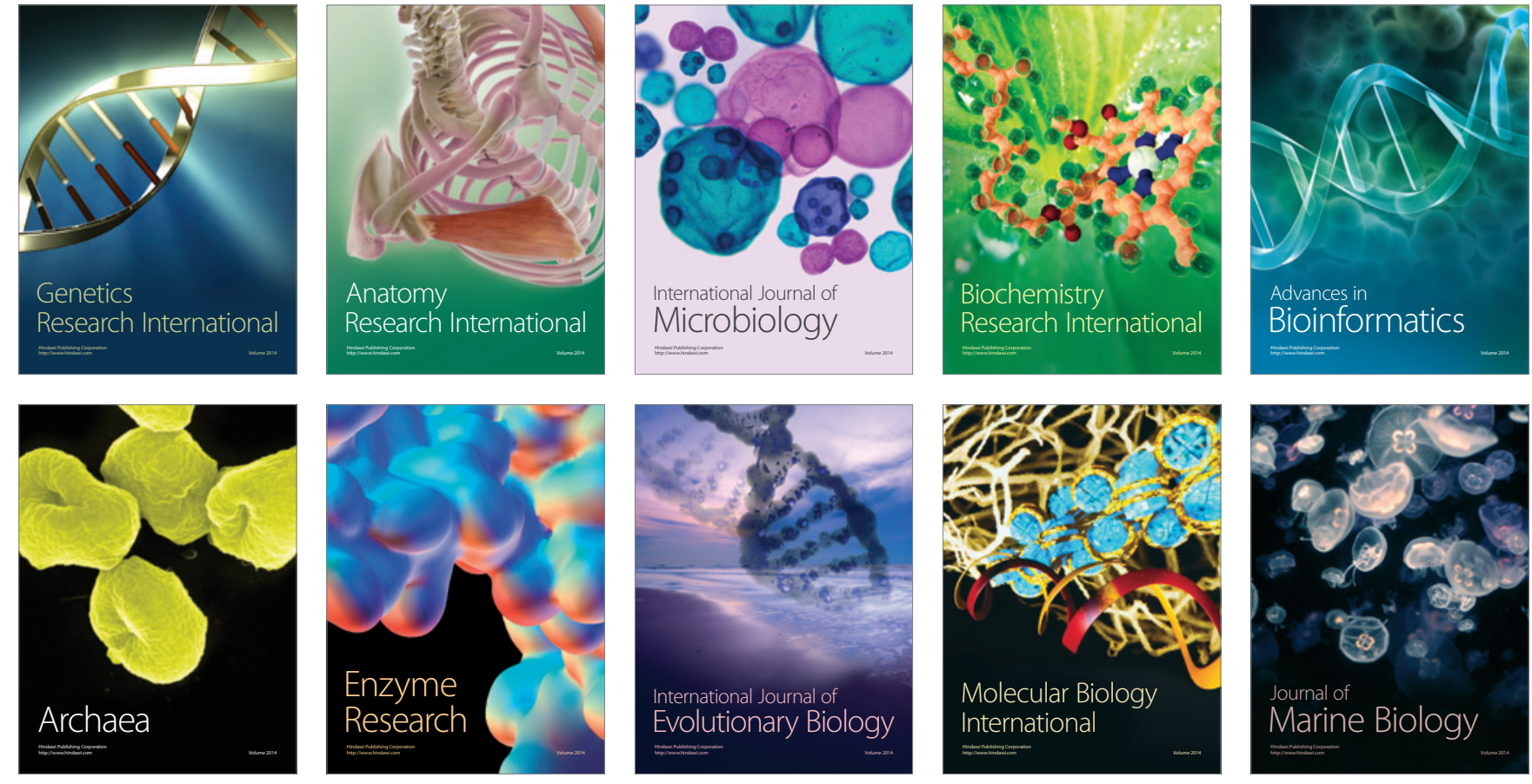